\title{
The Influence of Sewage System on the Functioning and Quality of Krakow's Watercourses
}

\author{
Marta Wardas-Lasoń \\ AGH University of Science and Technology, Faculty of Geology, Geophysics and Environment Protection, \\ 30 Mickiewicza Avenue, 30-059 Krakow, Poland \\ Correspondence should be addressed to Marta Wardas-Lasoń; wardas.marta@gmail.com
}

Received 11 July 2014; Revised 15 October 2014; Accepted 16 October 2014; Published 18 November 2014

Academic Editor: Karoly Nemeth

Copyright (C) 2014 Marta Wardas-Lasoń. This is an open access article distributed under the Creative Commons Attribution License, which permits unrestricted use, distribution, and reproduction in any medium, provided the original work is properly cited.

The content of heavy metals, pH, Eh, and EC were measured for the Vistula River and its two tributaries, Prądnik-Białucha and Wilga, functioning as rainwater collectors for Krakow. Water sediments were collected from several inlets of the rainwater canals into the Prądnik-Białucha and Wilga. The Vistula was examined to catch the change of water environment quality of those two tributaries as well as storm overflow systems installed on both its left and right bank. In this last case the research was based on the bottom sediments of the storm overflow system, from its inlets into the Vistula River, and from the inside of the waste water collector. Also, samples of suspension and water were collected where the bridges are located and also near Dębnicki bridge bottom sediments. The sampling was conducted in 2004-2005 but because of financial constraints after ten years the tests were not repeated, but it was decided to publish the results. The attention was paid to the $\mathrm{Cd}$ and $\mathrm{Pb}$ content in the sediments of sanitary catch basins from the Wilga and the Prądnik, in Vistula sediments from storm overflow system, in the siphon, in the suspension of Vistula waters, and in fine-grain river silts.

\section{Background}

The consequences of the functioning of a town are mainly felt by the water environment of the streams and the urbanized sections of its rivers. The quality of the natural environment of town watercourses is the effect of a complex impact of many factors, the destination, and usage of the catchment area, as well as its physiography, which is shaped by morphology, lithology, and hydrology. The geochemical composition of the river basin components also results from the intensity and pollution of the meteoric waters and the conditions of surface runoff. Also, for the water environment of the drainage area a significant anthropogenic factor is the kind and the way of sewage treatment released into water. According to the European Water Framework Directive (WFD) requirements, by the end of 2015 surface waters should attain "good ecological condition," which is denoted by biological quality elements, augmented by hydromorphological and physiochemical ones. The influence of storm water drains on the watercourses quality can be assessed on the basis of the European "cause and effect" procedure called DPSIR (driving force-pressure-state-impact response framework), ascribing to its elements direct and indirect priority factors $[1,2]$. In order to establish a character of degradation and to evaluate a possibility of restoration of the drainage basin, there are analyses of bottom sediments, hydromacrophytes or macrozoobenthos, the change of quality of the environmental indicators, including the bioindicators may reveal the causing agent, even if it operated in a distant past. [3-6]. While assessing different pollution indicators, many components of water environment are subjected to geochemical monitoring $[7,8]$. Evaluation of water environment from the perspective of metals concentration in the sediments of the bigger rivers more often than once a decade is not effective. Very slight differences are observed between different measurement periods [9-12] resulting mainly from geochemical changeability of river sediments, shaped by riverbed processes, and intensified by seasonal conditions of the drainage basin. Often, the level of metals concentration in river water suspension is taken as a more suitable indicator of how surface waters are burdened with metals $[13,14]$. That is why, from the perspective of rain drainage impact, it was decided 


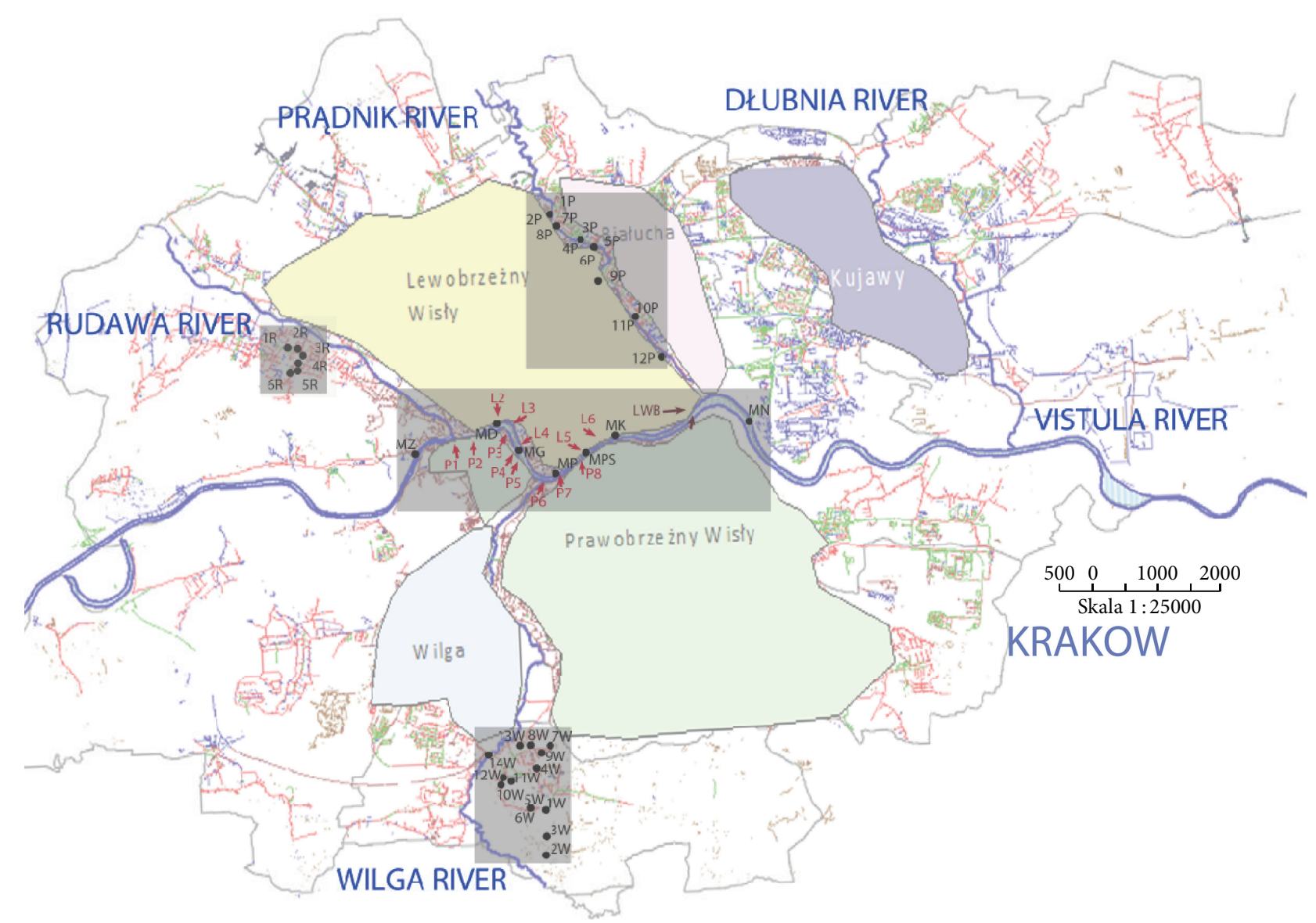

FIGURE 1: Sampling sites: rainwater drains; 1W-14W (the Wilga catchment area), 1P-12P (the Prądnik-Białucha catchment area), 1R-6R (from the Decius Park at the Wola Justowska - the Rudawa drainage area), right bank storm spillways (P1-P8), left bank (L2-L6), Vistula's Left Bank System sewerage siphon (LWS1-LWS4), bridge crossings over the Vistula River MZ, MD, MG, MP, MPS, MK, and MN (source: Municipal Department of Water Pipes and Sewers in Krakow).

to determine the changes of metal concentration both in sediments and in suspension. This is especially connected with the Vistula River, in the area marked by transverse sections, comprising the mouth areas of the Prądnik and Wilga, where some bridges are located.

\section{Sampling Sites and Methods}

The inlets of storm drains and spillways cause changes in hydromorphological condition, while quality of the rainwater is reliably characterized by physiochemical indicators, such as $\mathrm{pH}, \mathrm{Eh}, \mathrm{EC}$, and heavy metals, especially cadmium and lead concentrations in the water environment. Based on the Vistula River and its two tributaries, namely, the PrądnikBiałucha and Wilga, the influence of the storm water drains on the environment of the watercourses has been examined. Samples to be examined (water with suspension and sediments) were collected at the drain inlets into the Wilga and Prądnik. Also, the samples from storm spillways into the Vistula have been analyzed, coming from the right- and left-bank drainage areas of Krakow's combined sewers and some samples were taken where the seven bridges cross the river. The area sampled was chosen in two different parts of Krakow: the drainage basin of the Wilga river-this area mainly comprises farmland, numerous orchards, gardens, vegetable plots as well as forests, and also suburban development; the Prądnik Valley where there are predominantly garden allotments and meadows, some housing development as well as industrial areas, and roads. In the area of Decius Park, at Wola Justowska from objects of similar destination, some samples were taken with the purpose of being reference material for assessing the quality of water sewage sediments (Figure 1).

Samples, 14 from the Wilga drainage basin (1W-14W), 12 from the Prądnik Valley (1P-12P), and 6 from the Decius Park at the Wola Justowska, the Rudawa drainage area (1R$6 \mathrm{R})$, were collected during the year 2004 from the rainwater drainage system, that is, from the inlets of the rain culverts, roadside gutters, and drains for the Wilga and Prądnik. The samples of water, suspension, and sediments from the area of the seven Krakow's bridges across the Vistula River (Zwierzyniecki MZ, Grunwaldzki MG, Piłsudskiego MP, Powstańców Śląskich MPS, Kotlarski MK, and Nowohucki $\mathrm{MN}$ ) cover the location of the spillways and the mouths of the three tributaries (Figure 2).

The sampling sites were identified on ordinary maps and documentation maps of the Board of Municipal 


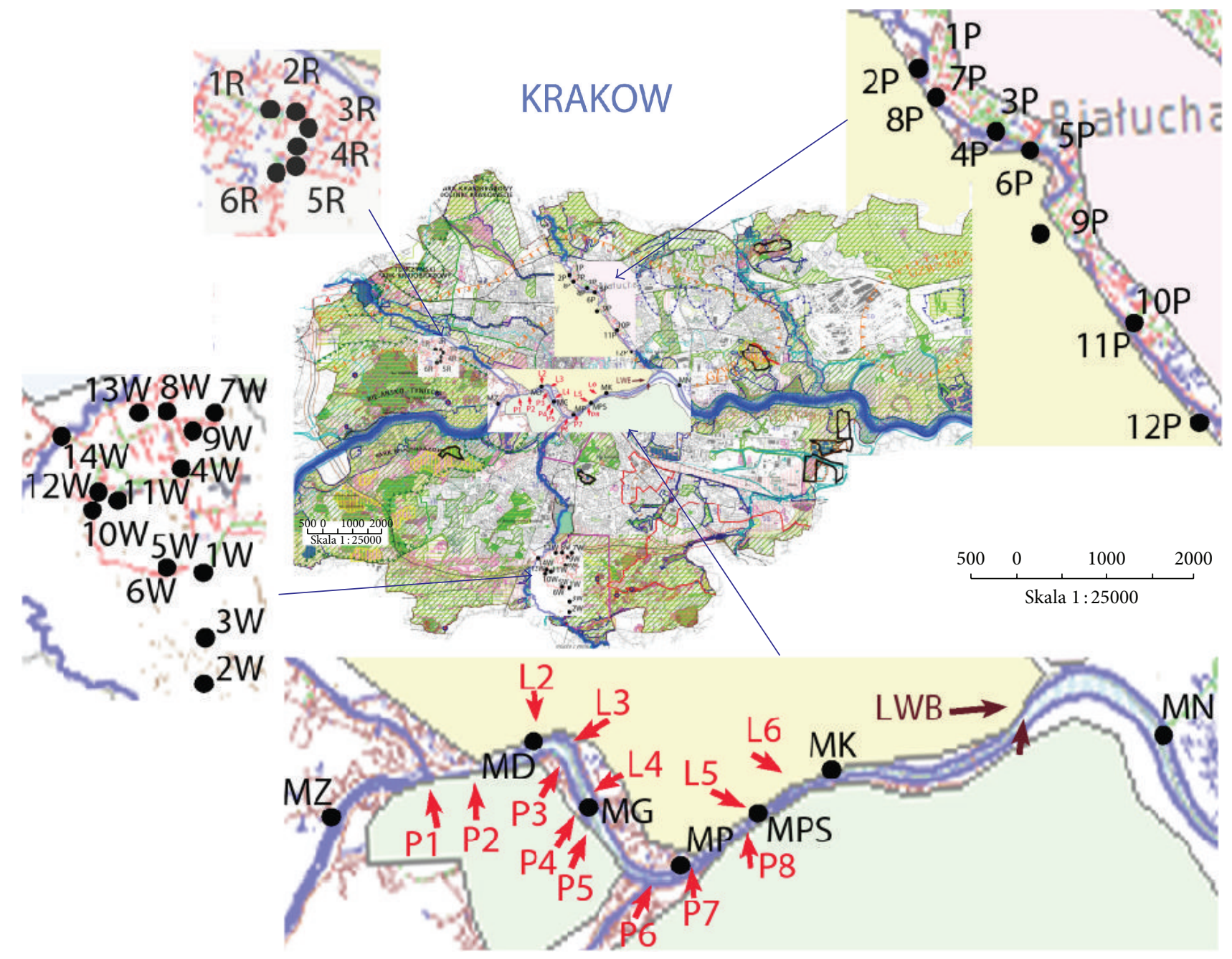

FIGURE 2: Bridge crossings and sampling sites from the Vistula River and its tributaries (source: Municipality of Krakow).

Management, (today's ZIKiT-the Department of Municipal Infrastructure and Transport), as well as using GPS. The sediments from storm spillways coming from close neighbourhood of hydrotechnical development, from the right bank (P1-P7) and the left bank (L2-L6) of the Vistula River, including a sample series of sediments from a siphon of the Vistula's Left Bank System (LWS), were taken in 2005. In order to check the geochemical and analytical changeability in the spillover area in the Dębnicki Bridge vicinity, MD, additional 3 samples MD1-MD3 of bottom sediment of the Vistula River were collected in the bank area and one MD4 at about $8 \mathrm{~m}$ from the spillover, as well as sediment sample MD5 from below the bridge. Additionally, in this area double samples were taken directly from the storm drain mouth, marked as P7a, P7b.

This helps with comparison and relating to the results obtained in other areas. Also in the case of the sediments coming from drain culvert inlets and storm spillways the methodology in situ and the laboratory procedures were observed. The only change introduced was including in metal analysis the grain fraction of the sediments $0.18-0.063 \mathrm{~mm}$ (usually, it was fine dust-silt $<0.063 \mathrm{~mm}$ and sludge fraction $<0.020 \mathrm{~mm}$ ). The total relative share of the two fractions better reflects the sediments quality, and, at the same time, it eliminates the influence of the graining effect on the metal content, that is, waste metal particles or pure quartz grains appearing, by coincidence, in the analyzed sample. The sediments from the storm water drainage system, that is, from the inlets of rain culverts, road gutters, and drainage ditches, were obtained with the help of scoop or plastic spoon, standing either in water or on the bank. The sediments from the storm spillovers were obtained standing on shipboard or on the embankment, but to get the LWS siphon deposits it was necessary to climb into the collector underground (Figure 3). Sampling and measurements of physiochemical markers in situ and ex situ, preparing, testing the suspension and sediments, and next extracting and marking the metals were conducted with the help of standard methods, in accordance with the environmental monitoring guidelines $[1,5,10,13,15$ 18 .

The water and suspension samples from the bridges area were taken with glass scoop held on steel line, lowered from 


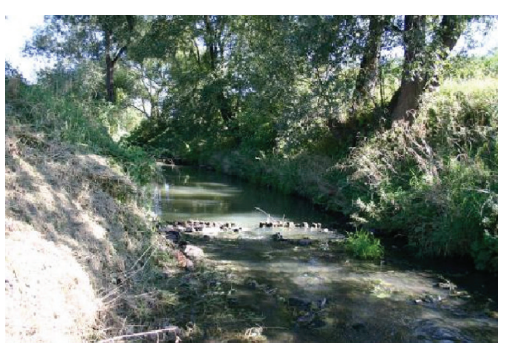

(a)

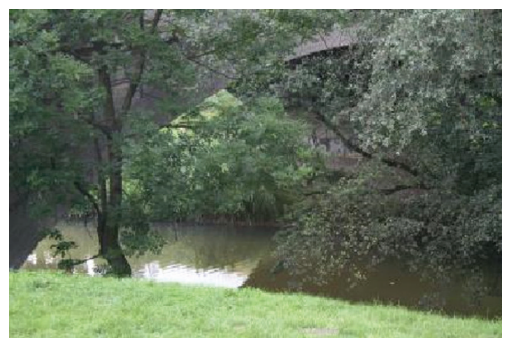

(a)

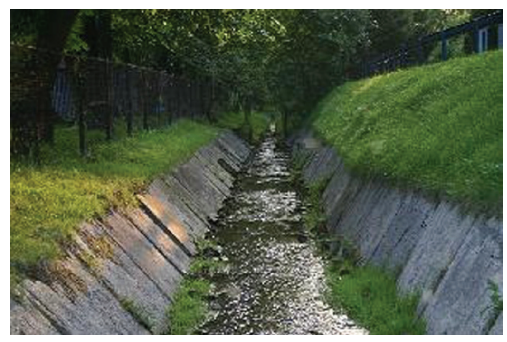

(d)

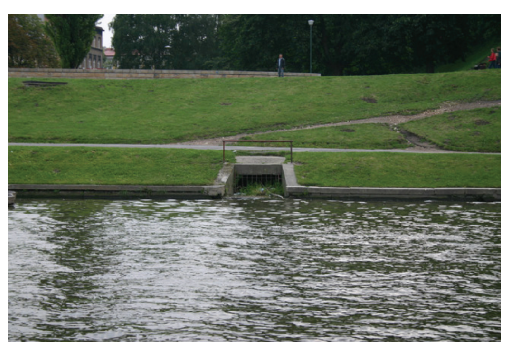

(e)

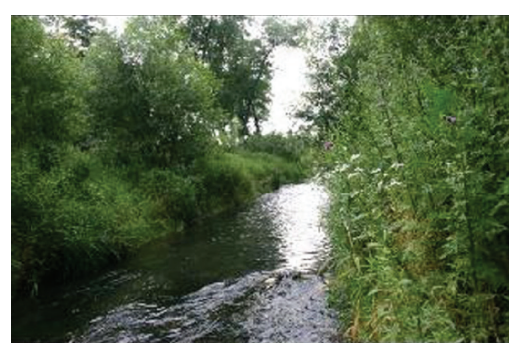

(b)

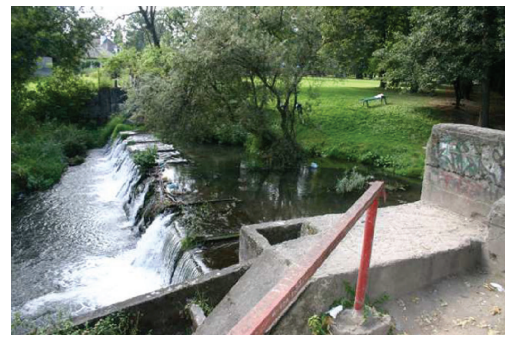

(b)

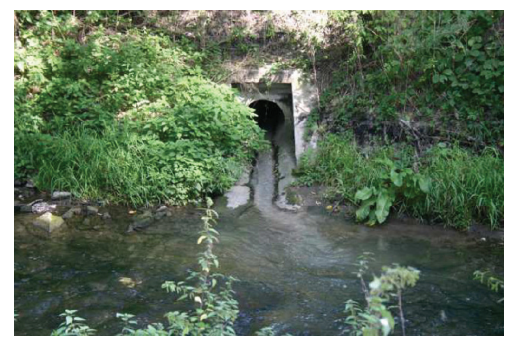

(b)

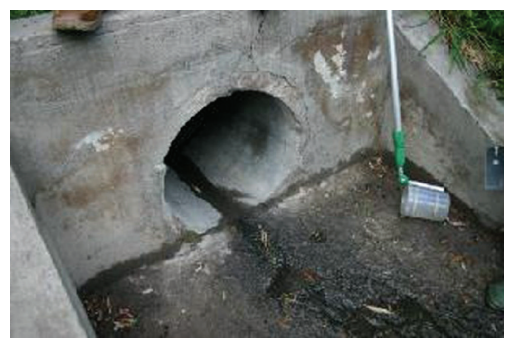

(b)

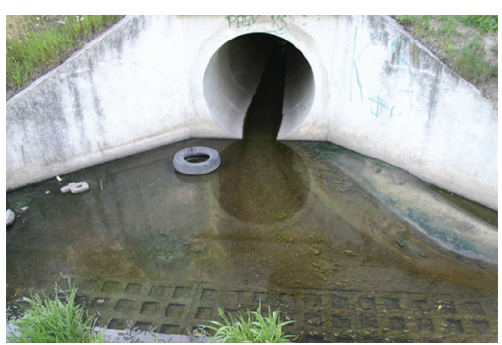

(b)

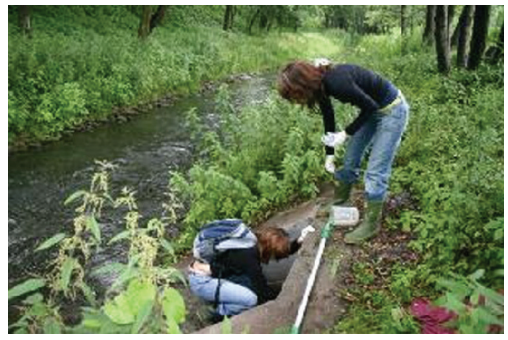

(b)

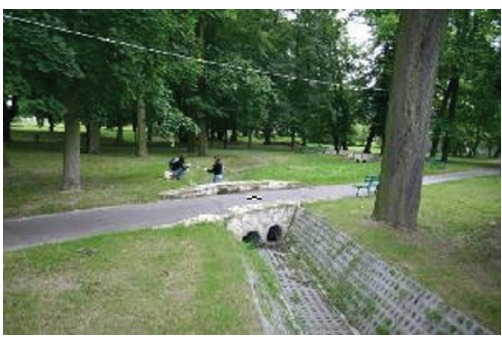

(c)

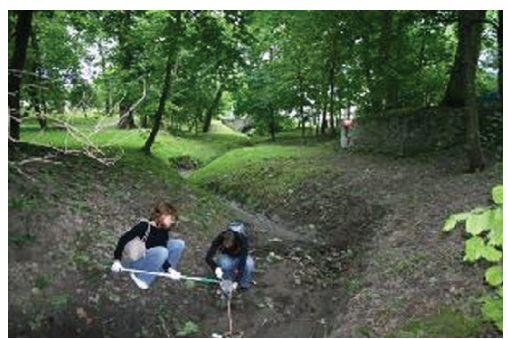

(c)

Figure 3: Sampling sites-examples: (a) the Wilga river, (b) the Prądnik-Białucha river, (c) drainage ditch in the Decius Park, (d) a drainage ditch in the Wilga drainage area, (e) and the spillways, the Vistula River.

the bridge. All the suspension samples were poured into $1000 \mathrm{~cm}^{3}$ polyethylene containers and the physiochemical indicators were measured on-site. In line with the research standards, membrane filters with the mesh of $0.45 \mu \mathrm{m}$ were used to separate the sediment, having first the $\mathrm{pH}, \mathrm{EC}$, and Eh measured in the water. Metal content was also determined in the dry fraction, which, roughly, corresponds to the concentration of the solved substances. Their mass was calculated after evaporating the filtered water samples at the temperature of $105^{\circ} \mathrm{C}$ and weighing the samples. In the laboratory, in the sediment samples which were used to prepare homogeneous suspensions of comparable volume density, the analogical tests were carried out. On-site a macroscopic description of the samples was made, including their grain-size distribution, colour, smell, and other characteristic features, such as the content of organic matter and presence of oil derivatives and live organisms. $\mathrm{PH}$ and Eh were measured with $\mathrm{CP}$ 104 waterproof ELMETRON IP67 equipped with proper electrodes; EC was checked with CC-101 conductometer. The metal content was determined by AAS (atomic absorption spectrometry), using PYE UNICAM SP9. The content of elements in the most and the least polluted sediments was controlled with spectrometer ICP-MS (ELAN 6100) and ICPOES (Optima 7300 DV), in an accredited hydrogeochemical 
laboratory (Certificate number $\mathrm{AB}$ 1050). Control and statistical assessment of accuracy and precision of the values determined by the AAS method were based on the reference materials (Sediment river 1646) and also the duplicates of samples were used. For the AAS method, a practical limit of detectability was established for $\mathrm{Cd}-0.01 \mathrm{mg} / \mathrm{dm}^{3}$, $\mathrm{Pb}-0.1 \mathrm{mg} / \mathrm{dm}^{3}, \mathrm{Cr}-0.05 \mathrm{mg} / \mathrm{dm}^{3}, \mathrm{Ni}-0.06 \mathrm{mg} / \mathrm{dm}^{3}, \mathrm{Cu}-$ $0.03 \mathrm{mg} / \mathrm{dm}^{3}, \mathrm{Zn}-0.03 \mathrm{mg} / \mathrm{dm}^{3}$. The estimated relative error of the mean value was less than $2 \%$. To sum up, all the materials were examined by applying uniform methodology, and the reference materials were analyzed for every 10th sample; metals were digested by hot extraction, in the $130^{\circ} \mathrm{C}$ with concentrated nitric acid $\left(10 \mathrm{~cm}^{3}\right)$, placed in mineralising flasks [19-21].

\section{Results and Discussion}

3.1. The Quality of Water Sediments in the Rainwater Drainage System Impact Area. Evaluating the rainwater sewerage impact on the water environment of the Wilga and Prądnik, the threat analysis was limited to cadmium and lead, for the Vistula environment being also chromium, nickel, and zinc. For comparison, the samples from a rainwater trench and a draining ditch form the area of Decius Park, at Wola Justowska, were tested. The research results of the quality of sediments collected form the rainwater drainage system installed in the catchment areas of these rivers are presented in Table 1.

The cadmium and lead contents in the $<0.063 \mathrm{~mm}$ fraction of the sediments coming from the Wilga area fluctuate within the range of $2-10 \mathrm{mgCd} / \mathrm{kg}$ and $24-117 \mathrm{mgPb} / \mathrm{kg}$, but the content of these elements is a bit lower in the $0.18-0.063 \mathrm{~mm}$ fraction, namely, $2-5 \mathrm{mgCd} / \mathrm{kg}$ and $7-$ $88 \mathrm{mgPb} / \mathrm{kg}$. The concentration of these metals in finer fraction $(<0.063 \mathrm{~mm})$ of the Prądnik area sediments fluctuates within the same limits as for the Wilga river; this is 2$10 \mathrm{mg} / \mathrm{kg}$ for $\mathrm{Cd}$ and twice as high maximum values for $\mathrm{Pb} 31-191 \mathrm{mg} / \mathrm{kg}$. Coarser fraction $(0.18-0.063 \mathrm{~mm})$ contains cadmium at the level of $2-10 \mathrm{mg} / \mathrm{kg}$ and lead at $45-161 \mathrm{mg} / \mathrm{kg}$. The cadmium and lead contents in the $<0.063 \mathrm{~mm}$ sediments fraction coming from rainwater sewers at Wola Justowska were determined as follows: $\mathrm{Cd} 3-6 \mathrm{mg} / \mathrm{kg}$ and $\mathrm{Pb} 58-$ $135 \mathrm{mg} / \mathrm{kg}$, and for the fraction $0.18-0.063$ for Cd $3-5 \mathrm{mg} / \mathrm{kg}$ and for $\mathrm{Pb} 41-116 \mathrm{mg} / \mathrm{kg}$.

In the sediment samples from the Wilga and Wola Justowska area the fraction 2-0.18 $\mathrm{mm}$ dominated; the second was that of $<0.063 \mathrm{~mm}$. In the Prądnik region the content was dominated by the finer fraction $(<0.063 \mathrm{~mm})$. Sediments $\mathrm{pH}$ values from the rainwater drains from the Wilga area fall within the range between 5.43 and 7.95; the negative value of oxidizing-reducing potential Eh from -290 to $-75 \mathrm{mV}$ testifies to strongly reducing conditions in the environment of weakly oxygenated sediments. The salinity is between $0.49-$ $2.00 \mathrm{mS} / \mathrm{cm}$. PH levels of the waste water sediments collected from the Prądnik area are more varied; they fall between 5.93 and 10.21, and the oxidizing-reducing potential Eh is also much more spread, from -287 to $341 \mathrm{mV}$, similarly to the conductivity values which fall within the range of $0.49-$ $9.10 \mathrm{mS}$. All the $\mathrm{pH}$ values of the sediments collected in the area belonging to Decius Park at Wola Justowska oscillate around the value of 7 , with one exception-that of 8.24. Eh values fluctuate from -211 to $177 \mathrm{mV}$, and the salinity is from 0.35 to $1.87 \mathrm{mS}$.

The suspended sediments collected from the Vistula at the vicinity of bridges showed (Table 3) cadmium contents $(\mathrm{mg} / \mathrm{kg})$ from 9.30 to 15.36 , and lead contents from 584.60 to 941.36 . At these places the water had 7.46-7.89 $\mathrm{pH}$ values, with the salinity of $4.385-5.315 \mathrm{mS} / \mathrm{cm}$ and positive oxidizingreducing potential Eh $231-251 \mathrm{mV}$. The sediments coming from left-hand bank Krakow spillways showed medium $\mathrm{pH}$ values-7.15; salinity $3.1 \mathrm{mS} / \mathrm{cm}$ oxidizing-reducing potential Eh was $45 \mathrm{mV}$, while from the right-hand Krakow, the $\mathrm{pH}$ values were on average at 6.99 , salinity at $3.59 \mathrm{mS} / \mathrm{cm}$, and Eh potential at $119.87 \mathrm{mV}$. About the $\mathrm{Cd}$ and $\mathrm{Pb}$ concentration $(\mathrm{mg} / \mathrm{kg})$, in the left-hand bank part of the town it was marked, respectively, within the ranges of 3.5-9.6 and 40.1-235.9, and in the right-hand part it was 4-24.3 and 49-290.7. The values of indicators of the components quality of the Vistula River environment are in Tables 2 and 3.

The values obtained for the sediments (fraction < $0.020 \mathrm{~mm}$ ) from the spillways and the indicator values for the suspended sediment and water quality collected at the bridges were collated according to the sampling points order along the course of the river.

The density of suspended sediments in the Vistula fluctuated between 0.1345 and $0.3236 \mathrm{~g} / \mathrm{dm}^{3}$. The concentration of the solved substances ranged from 1.923 to $3.615 \mathrm{mg} / \mathrm{dm}^{3}$. Extracting metals from the suspension and from the dry remains was conducted in the same way as with sediments. The analysis was carried out using the same instrument methodology and so they were regarded as comparable. The changes in concentration of the individual metals from rainwater drains sediments were compared to anion concentration in $10 \%$ water extract made for these samples. They were marked in filtered water solutions. Only sulphates and nitrates were taken into consideration because of negligibly small changes in high concentrations of chlorides and too low, below the determinable level, concentrations of fluorides and phosphates. General mineralization of the Vistula waters during the last ten years was, on average, $2.750 \mathrm{~g} / \mathrm{dm}^{3}$, with dominance of sodium ions, while, at the same time, the rainwater showed general mineralization up to $0.130 \mathrm{~g} / \mathrm{dm}^{3}$, with the dominance of calcium, magnesium, and sulphate ions [25].

The sediments in the storm spillover systems area need to be considered as particular indicators of rainwater drains impact; that is why the heavy metals content was determined in all the fractions isolated, namely, in the sandy fraction > $0.063 \mathrm{~mm}$, the medium one $0.063-0.020 \mathrm{~mm}$, and the sludge one $<0.020 \mathrm{~mm}$. More detailed research was also conducted in the case of LWS* (Vistula's Left Bank System) sewerage siphon, where, apart from sediments profile from the area of the sewage collector old inlet into the Vistula, LWS1, also the underground infrastructure sediments were sampled from the bottom of the siphons LWS 2-3, and from the collector bottom LWS4 (Table 4). Heavy metals were determined by AAS method in two separate sessions; system (LWS) with its 
TABle 1: Levels of pH, oxidizing-reducing potential Eh, and electrolytic conductivity EC of the sediments collected in the Wilga, Prądnik, and at Wola Justowska (park-the reference area).

\begin{tabular}{|c|c|c|c|c|c|c|c|}
\hline \multirow{4}{*}{ Sample symbol } & \multirow{4}{*}{$\mathrm{pH}$ level } & \multirow{4}{*}{$\mathrm{Eh}[\mathrm{mV}]$} & \multirow{4}{*}{$\mathrm{EC}[\mathrm{mS} / \mathrm{cm}]$} & \multicolumn{2}{|c|}{$\mathrm{Cd}$} & \multicolumn{2}{|c|}{$\mathrm{Pb}$} \\
\hline & & & & \multicolumn{4}{|c|}{$[\mathrm{mg} / \mathrm{kg}]$} \\
\hline & & & & $0.18-0.063$ & $<0.063$ & $0.18-0.063$ & $<0.063$ \\
\hline & & & & \multicolumn{4}{|c|}{$[\mathrm{mm}]$} \\
\hline \multicolumn{8}{|c|}{ Wilga catchment area } \\
\hline $1 \mathrm{~W}$ & 5.43 & -85 & 1.99 & 3 & 8 & 38 & 107 \\
\hline $2 \mathrm{~W}$ & 6.67 & -165 & 1.36 & 3 & 7 & 45 & 104 \\
\hline $3 \mathrm{~W}$ & 6.76 & -235 & 1.00 & 4 & 6 & 40 & 117 \\
\hline $4 \mathrm{~W}$ & 7.9 & -88 & 1.67 & no fraction & 10 & no fraction & 93 \\
\hline $5 \mathrm{~W}$ & 7.95 & -120 & 1.71 & 2 & 5 & 28 & 68 \\
\hline $6 \mathrm{~W}$ & 6.68 & -132 & 1.09 & 3 & 7 & 15 & 107 \\
\hline $7 \mathrm{~W}$ & 6.28 & -262 & 1.04 & 5 & 7 & 88 & 114 \\
\hline $8 \mathrm{~W}$ & 6.68 & -205 & 1.73 & 3 & 6 & 50 & 111 \\
\hline $9 \mathrm{~W}$ & 6.83 & -150 & 1.90 & 2 & 5 & 53 & 102 \\
\hline $10 \mathrm{~W}$ & 7.61 & -76 & 1.37 & 3 & 2 & 7 & 24 \\
\hline $11 \mathrm{~W}$ & 6.14 & -113 & 1.63 & 2 & 4 & 20 & 75 \\
\hline $12 \mathrm{~W}$ & 6.49 & -290 & 2.00 & 4 & 7 & 59 & 105 \\
\hline $13 \mathrm{~W}$ & 7.78 & -75 & 0.49 & 2 & 5 & 36 & 77 \\
\hline $14 \mathrm{~W}$ & 6.27 & -140 & 1.68 & 3 & 7 & 24 & 89 \\
\hline \multicolumn{8}{|c|}{ Prądnik catchment area } \\
\hline $1 \mathrm{P}$ & 10.21 & -3 & 1.09 & 5 & 7 & 59 & 116 \\
\hline $2 \mathrm{P}$ & 9.08 & -110 & 0.49 & 8 & 8 & 126 & 191 \\
\hline $3 \mathrm{P}$ & 7.60 & -14 & 1.45 & 10 & 10 & 72 & 57 \\
\hline $4 \mathrm{P}$ & 8.20 & -287 & 1.83 & 7 & 6 & 120 & 133 \\
\hline $5 \mathrm{P}$ & - & - & 8.60 & 8 & 6 & 145 & 73 \\
\hline $6 \mathrm{P}$ & 6.82 & -165 & 6.29 & 5 & 6 & 91 & 104 \\
\hline $7 \mathrm{P}$ & 6.23 & 341 & 0.58 & 7 & 2 & 85 & 31 \\
\hline $8 \mathrm{P}$ & 7.48 & -91 & - & 3 & 4 & 45 & 63 \\
\hline 9P & 6.28 & -169 & 9.10 & 4 & 4 & 55 & 54 \\
\hline $10 \mathrm{P}$ & 5.93 & 130 & 5.93 & 4 & 3 & 77 & 53 \\
\hline $11 \mathrm{P}$ & 7.61 & 82 & - & 2 & 4 & 52 & 147 \\
\hline $12 \mathrm{P}$ & 7.64 & -153 & 0.87 & 10 & 5 & 161 & 79 \\
\hline \multicolumn{8}{|c|}{ Wola Justowska area } \\
\hline $1 \mathrm{R}$ & 7.14 & -130 & 1.87 & 3 & 3 & 61 & 58 \\
\hline $2 \mathrm{R}$ & 7.84 & 177 & 0.89 & 5 & 6 & 116 & 135 \\
\hline $3 \mathrm{R}$ & 7.53 & 62 & 0.51 & 4 & 4 & 78 & 129 \\
\hline $4 \mathrm{R}$ & 7.57 & -172 & 1.03 & 3 & 5 & 41 & 114 \\
\hline $5 \mathrm{R}$ & 8.24 & 131 & 0.35 & 4 & 3 & 53 & 80 \\
\hline $6 \mathrm{R}$ & 7.31 & -211 & 0.43 & 5 & 5 & 72 & 100 \\
\hline
\end{tabular}

collector on the left of the river and the Right Bank System (PWS) with its own collector on the right bank.

\subsection{Urbanization in the Catchment Areas of the Wilga and} Pradnik and Its Impact on the Landscape and Environment. In the Vistula draining basin, in Krakow's vicinity, there are many hydrotechnical and engineering structures, which results in a far-from-natural condition, also with respect to all the elements of water environment. And so, $\mathrm{pH}, \mathrm{EC}$, chosen heavy metals content, $\mathrm{Mn}$ and Fe in solid sediment particles and suspension, and fluorides, chlorides, nitrates, sulphates, and phosphates concentrations are accepted as indicators of the pressure created by sewage system elements. It has been accepted that in the areas with separate sewerage, the rainwater receivers are trenches and watercourses. On the map (Figure 1) brown colour signifies combined sewers, red sanitary sewers, and green rainwater drains. The streams and watercourses in the drainage basins of the Wilga and Prądnik are subjected to various kinds of anthropopression in the form of hydrotechnical developments and numerous access limitations, not being the expected element of unifying specific forms of management. Many sections of the natural riverbed have been eliminated and the stream is directed into pipe culverts of significant length, especially when it runs 
TABLE 2: Changeability of physiochemical indicators in the samples of sediments and the Vistula water.

\begin{tabular}{|c|c|c|c|c|c|c|c|c|c|c|c|c|c|c|}
\hline Sample symbo & $\mathrm{Cd}$ & $\mathrm{Cr}$ & $\begin{array}{l}\mathrm{Ni} \\
\text { Fr. }\end{array}$ & $\begin{array}{r} \\
{[\mathrm{Cu}} \\
{[\mathrm{mg} / \mathrm{k}} \\
<0.0 \\
>0.45 \\
<0.45\end{array}$ & $\begin{array}{l}\mathrm{Pb} \\
\mathrm{g}] \\
20 \mathrm{~mm} \\
\mu \mathrm{m}^{\mathrm{s}} \\
\mu \mathrm{m}^{\mathrm{w}}\end{array}$ & $\mathrm{Zn}$ & $\mathrm{Mn}$ & $\mathrm{NO}_{3}{ }^{-}$ & $\mathrm{SO}_{4}{ }^{2-}$ & $\mathrm{pH}$ & $\begin{array}{c}\text { TDS }^{*} \\
\mathrm{EC}^{* *} \\
{\left[\mathrm{mg} / \mathrm{dm}^{3}\right]^{*}} \\
{\left[\mathrm{mS} / \mathrm{cm}^{* *}\right.}\end{array}$ & {$[\mathrm{mV}]$} & Fr. $<0.020 \mathrm{~mm}$ & $\begin{array}{c}\text { Suspended } \\
\text { sediment density }\end{array}$ \\
\hline$\overline{\mathrm{MZ}^{\mathrm{w}}}$ & 1.5 & 0.6 & 13 & 3 & 3 & 18 & - & 4.2 & 63.6 & - & $2.38^{*}$ & - & - & - \\
\hline $\mathrm{MZ}^{\mathrm{s}}$ & 11.1 & 138 & 150 & 145 & 692 & 1379 & - & - & - & $7.53^{* *}$ & $5.31^{* *}$ & $232^{* *}$ & - & 0.1345 \\
\hline $\mathrm{P} 1$ & 5.7 & 3.5 & 10 & 17 & 42 & 672 & 476 & 13.2 & 116.5 & 6.81 & 3.43 & 191 & 20.81 & - \\
\hline $\mathrm{P} 2$ & 8.8 & 49.8 & 25 & 42 & 236 & 165 & 579 & 20.1 & 145.0 & 7.04 & 3.96 & 114 & 1.78 & - \\
\hline $\mathrm{MD}^{\mathrm{w}}$ & 1.2 & 1.2 & 12 & 3 & 2 & 19 & - & 15.2 & 128.7 & - & $2.49^{*}$ & - & - & - \\
\hline $\mathrm{MD}^{\mathrm{s}}$ & 12.0 & 202 & 160 & 182 & 690 & 1968 & - & - & - & $7.46^{* *}$ & $5.12^{* *}$ & $231^{* *}$ & - & 0.3236 \\
\hline L2 & 13.1 & 7.0 & 21 & 69 & 103 & 1069 & 400 & 37.3 & 95.1 & - & - & - & 12.41 & - \\
\hline P3 & 9.2 & 19.0 & 26 & 54 & 82 & 939 & 1428 & 17.2 & 115.0 & 7.20 & 3.28 & 128 & 4.52 & - \\
\hline L3 & 4.0 & 49.8 & 7 & 3 & 49 & 95 & 202 & 12.7 & 116.0 & - & - & - & 12.41 & - \\
\hline $\mathrm{MG}^{\mathrm{w}}$ & 1.1 & 1.2 & 10 & 3 & 3 & 14 & - & 14.5 & 172.5 & - & $3.61^{*}$ & - & - & - \\
\hline $\mathrm{MG}^{\mathrm{s}}$ & 15.4 & 150 & 160 & 174 & 668 & 1707 & - & - & - & $7.63^{* *}$ & $4.48^{* *}$ & $236^{* *}$ & - & 0.3020 \\
\hline P4 & 8.1 & 34.5 & 3 & 24 & 117 & 422 & 231 & 10.5 & 116.9 & 7.05 & 3.70 & 200 & 75.20 & - \\
\hline L4 & 9.5 & 7.7 & 15 & 25 & 218 & 361 & 251 & 9.4 & 100.0 & 7.18 & 3.46 & 148 & 56.90 & - \\
\hline P5 & 3.5 & 34.9 & 7 & 12 & 191 & 197 & 207 & 8.4 & 105.2 & 6.63 & 3.80 & -28 & 16.84 & - \\
\hline P6 & 9.6 & 47.2 & 23 & 98 & 211 & 1093 & 332 & 7.5 & 112.9 & 7.03 & 3.11 & 148 & 12.15 & - \\
\hline $\mathrm{MP}^{\mathrm{w}}$ & 1.6 & 0.8 & 13 & 3 & 4 & 18 & - & 14.7 & 367.3 & - & $2.49^{*}$ & - & - & - \\
\hline $\mathrm{MP}^{\mathrm{s}}$ & 4.3 & 161 & 142 & 157 & 836 & 1563 & - & - & - & $7.67^{* *}$ & $4.69^{* *}$ & $238^{* *}$ & - & 0.2166 \\
\hline P7 & 7.3 & 16.2 & 10 & 19 & 40 & 258 & 598 & 15.1 & 98.0 & 6.93 & 3.63 & 20 & 3.54 & - \\
\hline P8 & 6.7 & 18.2 & 11 & 38 & 210 & 434 & 261 & 11.0 & 113.5 & 7.21 & 3.64 & 186 & 28.43 & - \\
\hline MPS $^{\mathrm{w}}$ & 1.6 & 1.1 & 13 & 3 & 4 & 16 & - & 15.2 & 137.2 & - & $2.38^{*}$ & - & - & - \\
\hline MPS $^{s}$ & 9.3 & 116 & 107 & 132 & 585 & 1244 & - & - & - & $7.67^{* *}$ & $5.19^{* *}$ & $251^{* *}$ & - & 0.1897 \\
\hline L5 & 11.0 & 17.4 & 14 & 41 & 92 & 539 & 358 & 9.3 & 113.3 & 7.16 & 3.72 & 112 & 16.84 & - \\
\hline L6 & 24.3 & 55.8 & 19 & 101 & 100 & 1265 & 300 & 1.1 & 169.8 & 7.10 & 2.12 & -124 & 24.14 & - \\
\hline $\mathrm{MK}^{\mathrm{w}}$ & 1.4 & 0.9 & 13 & 3 & 6 & 16 & - & 14.3 & 233.9 & - & $1.92^{*}$ & - & - & - \\
\hline $\mathrm{MK}^{\mathrm{s}}$ & 11.4 & 142 & 162 & 206 & 707 & 2037 & - & - & - & $7.89^{* *}$ & $4.88^{* *}$ & $239^{* *}$ & - & 0.1367 \\
\hline LSW & 12.6 & 40.7 & 47 & 369 & 290 & 1698 & 57 & - & - & - & - & - & - & - \\
\hline $\mathrm{MN}^{\mathrm{w}}$ & 1.1 & 0.6 & 10 & 4 & 7 & 24 & - & 14.3 & 233.9 & - & $3.20^{*}$ & - & - & - \\
\hline $\mathrm{MN}^{s}$ & 12.0 & 271 & 171 & 357 & 941 & 4422 & - & - & - & $7.56^{* *}$ & $4.38^{* *}$ & $250^{* *}$ & - & 0.2906 \\
\hline
\end{tabular}

P1-P8, L1-L6: storm spillovers, M: bridges (Z: Zwierzyniecki, D: Dębnicki, G: Grunwaldzki, P: Piłsudskiego, PS: Powstańców Śląskich, K: Kotlarski, and N: Nowohucki); w: water (dry residue), s: water with suspension, ${ }^{*}$ TDS: Total Dissolved Solids-filtered water, ${ }^{* *}$ water with suspension.

under road junctions. A significant part of the riverbed is "schematically" straightened and rebuilt, usually with manmade materials and the watercourses are devoid of biological revitalization, which increases the risk of flooding.

Physiochemical pressure and condition indicators for the Prądnik, Wilga, and also the Vistula catchment areas within the municipality of Krakow have been researched many times. Sediments are the most often monitored element of the water environment quality and in the years 19902005 the sampled sediments of Krakow rivers showed, in the $<0.2 \mathrm{~mm}$ fraction, heavy metal concentration in the range of the following: $\mathrm{Zn} \mathrm{39-2504}$, on average 339, $\mathrm{Pb}<5-4519$, on average 53 , Cu 1-268, on average $20, \mathrm{Cr} 1-759$, on average 22 , Ni 1-83, on average 17 , and $\mathrm{Cd}<0.5-135$ [7].

In the author's own research from 2004 the metal content $(\mathrm{mg} / \mathrm{kg})$ in the Białucha bottom sediments had lower values:
185-732 Zn, 44-122 Pb, 11-77 Cu, 4.0-45 Ni, 4.5-33 Cr and 2.7-7.6 Cd, but in the suspended sediment samples the highest concentration of $\mathrm{Zn}, \mathrm{Pb}, \mathrm{Cd}, \mathrm{Cu}$, and $\mathrm{Ni}$ was established [26]. The research carried out in 2005 based on the sediments of one of the Białucha tributaries, the stream of Sudoł Dominikański [19] revealed metal concentrations $(\mathrm{mg} / \mathrm{kg})$ in the range of $47-943 \mathrm{Zn}, 16-124 \mathrm{~Pb}$, and 7-73 Cu, similar to those registered for the Białucha.

Similar research was carried for the Wilga river sediments, collected in 2001 and 2002 [27]. The metal concentrations $(\mathrm{mg} / \mathrm{kg})$ showed diversification as follows: $43-372$ Zn, 8-184 Cu, 15-70 Pb, < 1-46 Cr, 8-31 Ni, and 1-16 Cd. The pollution of suspended sediments $(\mathrm{mg} / \mathrm{kg})$ for the Wilga river was significantly higher than for the Prądnik drainage area, and it reached the values of 1325 for $\mathrm{Zn}, 517$ for $\mathrm{Cu}$, 506 for $\mathrm{Cr}, 320$ for $\mathrm{Pb}, 250$ for $\mathrm{Ni}$, and 60 for $\mathrm{Cd}$. The Wilga 
TABLE 3: Heavy metals content $[\mathrm{mg} / \mathrm{kg}]$ of the Vistula sediments from storm spillover area.

\begin{tabular}{|c|c|c|c|c|c|c|}
\hline Sample symbol ${ }^{*}$ & $\begin{array}{c}\text { Fraction } \\
{[\mathrm{mm}]}\end{array}$ & \multicolumn{5}{|c|}{ [mg/kg] } \\
\hline \multirow{2}{*}{ P7a } & $>0.063$ & 1059 & 215 & 71 & 35 & 18 \\
\hline & $<0.063$ & 914 & 218 & 75 & 37 & 16 \\
\hline \multirow{2}{*}{ P7b } & $>0.063$ & 874 & 176 & 65 & 34 & 18 \\
\hline & $<0.063$ & 706 & 178 & 57 & 29 & 9 \\
\hline \multirow{3}{*}{ MD1 } & $>0.063$ & 737 & 687 & 52 & 35 & 13 \\
\hline & $0.063-0.020$ & 718 & 134 & 66 & 29 & 10 \\
\hline & $<0.020$ & 1541 & 313 & 290 & 42 & 54 \\
\hline \multirow{3}{*}{ MD2 } & $>0.063$ & 605 & 154 & 75 & 35 & 18 \\
\hline & $0.063-0.020$ & 2827 & 422 & 28 & 29 & 12 \\
\hline & $<0.020$ & 1419 & 434 & 215 & 20 & 92 \\
\hline \multirow{3}{*}{ MD3 } & $>0.063$ & 1087 & 277 & 69 & 62 & 59 \\
\hline & $0.063-0.020$ & 510 & 169 & 124 & 32 & 48 \\
\hline & $<0.020$ & 1664 & 434 & 205 & 54 & 83 \\
\hline \multirow{3}{*}{ MD4 } & $>0.063$ & 1427 & 352 & 344 & 25 & 102 \\
\hline & $0.063-0.020$ & 1239 & 238 & 235 & 14 & 73 \\
\hline & $<0.020$ & 2179 & 346 & 718 & 39 & 136 \\
\hline \multirow{3}{*}{ MD5 } & $>0.063$ & 1315 & 253 & 95 & 59 & 23 \\
\hline & $0.063-0.020$ & 4304 & 787 & 320 & 98 & 89 \\
\hline & $<0.020$ & 1740 & 340 & 302 & 26 & 65 \\
\hline Background $^{* *}$ & $<0.063$ & 110 & 45 & 40 & 50 & 2 \\
\hline
\end{tabular}

${ }^{*}$ The Dębnicki most vicinities, ${ }^{* *}$ Helios-Rybicka 1991 [22].

TABLE 4: The heavy metals content [mg/kg] in the sediment samples from storm spillover sediment.

\begin{tabular}{lccccc}
\hline Sample symbol & Zn & Pb & Cu & Cr \\
& \multicolumn{5}{c}{$\begin{array}{c}\text { Fraction }<0.063 ~ \\
\text { mg/m } / \mathrm{kg}\end{array}$} \\
\hline LWS1 & 1633 & 231 & 590 & 45 & 12 \\
LWS2 & 1916 & 295 & 370 & 51 & 12 \\
LWS3 & 864 & 320 & 57 & 19 & 13 \\
LWS4 & 2380 & 316 & 460 & 49 & 13 \\
\hline
\end{tabular}

${ }^{*}$ LWS (Vistula’s Left Bank System).

sediments, sampled in the 90s, showed slightly different metal concentrations $(\mathrm{mg} / \mathrm{kg})$ but still they were close to those registered after about 15 years, that is, 185-715 Zn, 38-196 Pb, 27-195 Cu, 3-98 Ni, 3-52 Cr, and 1-8 Cd. Potential metal sources such as leachates and surface runoffs from industrial areas, settling ponds, dual clearways, or bridge crossings are responsible for local geochemical anomalies [21]. Another cause of changeability is seen in the Wilga hydromorphological elements; the meanders, especially, generate increased concentrations of metals in sediments.

3.3. The Impact of the Rainwater Drainage System on Water Environment in Urbanized Areas-The Methods of CauseEffect Analysis of the Impact of Urbanization on Hydrosphere. Structural features of surface waters make it possible to choose the parameters which belong to standard hydromorphological quality elements, such as the riverbed, bank ecosystem, and floodplains. According to WFD, a very good status corresponds to completely or almost completely undisturbed, by anthropogenic activity, conditions and it allows the organisms to migrate freely. A high ecological status of a watercourse is determined by hydrological regime, the river's continuity, its morphological conditions, and biological elements of the watercourse quality, which signify a natural or almost natural water flow process. These are model reference conditions, where there are no emissions which modify the physical, chemical, and biological profile of the watercourse, and so no causing factors, especially no elements of hydrotechnical development, are present.

Analysing the causes and effects of unfavourable impact of human activity on natural environment, in the case of interaction of rainwater drainage systems and watercourses, the following should be included: $\mathrm{D}$-driving forces changing the drainage areas, sealing the surface through hydrotechnical effects, and self-acting surface sealers; installing the inlets of the rainwater drains, storm spillways, and parameters changing the hydromorphological condition of a watercourse, that is, the sewage and rainwater; surface runoff, solid and wet deposition, the size and characteristics of sewage drainage area, draining of bridges and other engineering constructions in the area of the river basin; rainfall and catch basin characteristics shaping the size and kind of emission; $\mathrm{P}-$ pressures that they create-emission of sewage and rainwater, the dynamics and intensity of sewage and rainwater inflow, and the dynamics and intensity of the outflow, solid and solved mineral substances and chemical compounds and waste with the products of its decomposition; the construction elements of hydrotechnical objects and products of their corrosion; $\mathrm{S}$ - on the state of environmentpollution of water, suspension, water sediments, and biological elements coming from heavy metals, chlorides, nitrates, sulphates, phosphates, oxygen consuming substances, and nutrients; I-the impact this has on ecosystems or human health-impact on abiotic components of the water environment, causing acidity $-\mathrm{pH}$, alkalization, salinity-PEW, eutrophication-Eh, mechanical change in deposits content, adding extraneuos solid phases (rubbish), bioindicators; Rresponses that aim to influence one or several D,P,S,I-strips of protective greenery, bars in storm outlets and spillways, quality control of rainwater, preventing the emission of gasses, and dust into the air, protecting river landscape, catching, and introducing into combined sewerage the leachate from engineering developments being drained.

\subsection{Legal Instruments for Protection of Water Environment} in Urbanized Areas. To minimize negative impact of rainfall and snow melt drained form streets, squares, warehouse buildings or roofs, numerous regulations have been adopted in legislation of many countries, with Poland included. They are based on monitoring and scientific research, showing still new threats resulting from anthropopression. Analysing the causes of rainwater pollution in urbanized areas, also geoenvironmental factors are taken into account, such as susceptibility to erosion as a result of surface runoff, pollution of meteoric waters, degree and characteristics of land development, the kind and condition of hardened 
surfaces, intensity of transportation traffic, and also other factors including the way the drainage system is cleaned, the defrosting methods applied in the area, or the intensity of construction works. As the research concerning emissions of priority substances shows, roof runoff can generate $\mathrm{Zn}$ and $\mathrm{Cu}$ concentrations $\left(\mathrm{mg} / \mathrm{dm}^{3}\right)$ in the range of, respectively, 4.5 and 1.6. Within the transit route areas the biggest problem is lead emission $\left(\mathrm{mg} / \mathrm{dm}^{3}\right)$ in the range of $0.20-0.30$, and in the urban areas, far from the roads-at the level of 0.08 . The most significant amounts $\left(\mathrm{mg} / \mathrm{dm}^{3}\right)$ of chlorides are created during snow melt from the streets-3500, dual clearways1600 , urban areas -1500 , and parking places -700 ; in the runoff from the drainage of residential and small business area the concentration is assessed at $50 \mathrm{mg} / \mathrm{dm}^{3}$ [27-29].

The emission and imission environmental standards binding in Poland state the limits concerning physiochemical indicators and specify, in detail, the conditions regarding waste-water management, and this concerns mainly the treatment of meteoric waters. There is no possibility of treating all rain waste water, therefore a necessity to discharge the excess storm water, untreated, directly into a receiver. The most justified solution is using separated sewer systems, which, for economic reasons, must take mainly real environmental threats into account, when making decisions concerning the necessity of rainwater treatment before releasing it into receiving waters or ground. There is a general rule forbidding the inflow of communal and residential waste into rainwater drains, but also meteoric and drained waters cannot be let into sanitary sewers. In the case of combined sewers the standards for meteoric waters drained by the sewerage have not been specified; however, if there is a probability that the rain or melt water can be contaminated they should go to the sewers with water-treatment plants and collectors destined for this type of waters, less often into the ground. The condition that must be met is the presence of a layer, not thinner than $3 \mathrm{~m}$, isolating the highest usable water-bearing level. There are no schemata referring to draining and treating meteoric waters, because these depend on topography of the land, character of the buildings, and especially usefulness of the receivers and the environmental requirements shaped by physiography and development plans for the area. A surface watercourse destined to collect rainwater must have specific flow characteristics, calculated on the basis of water levels. The receiver should guarantee flow of the waters in the watercourse's bed. In accordance with the DPSIR model, all causing pressure and state agents have their reflection mainly in the sensitivity of the water environment. To assess the water environment the following sensitivity scale is used: BW-very sensitive water environment such as drinking water reservoir, salmonidae farms, well head areas, or other specially protected areas. W-sensitive water environment used, for example, for recreational purposes, but also the existence of dense hydrographic network or waterlogged areas; MW-less sensitive water environment [30].

In Krakow vicinity the density of river network is significant and it approaches about $1 \mathrm{~km}$ for $\mathrm{km}^{2}$ [31,32]. Poland, also because of belonging to the Baltic Sea drainage area, has been included in the category of sensitive receivers; that is why, especially in the urbanized areas, there are environmental standards in force, concerning, among others, draining rain waters from roads, especially from bridge crossings. The legislator recommends using retention and infiltration basins, infiltration trenches, green ditches, absorption wells, evaporation tanks, or mechanical treatment plants for rainwater. Heavy metals pose the most serious problem and they belong to lasting pollutants of high priority. High concentrations of lead and zinc are found in sewage coming from the snow, melting at the roadsides; that is why it is collected from the towns and transported to water treatment plants. Meteoric waters receivers, to be protected in case of extraordinary environmental threats, are, at the outlets of rainwater canals, equipped with gates which enable the inflow to be cut off.

\subsection{Identification of the Impact of the Rainwater Sewage} System in the Krakow Area-The Drainage System in Krakow. Krakow is an almost 800000 agglomeration which has two separate drainage systems with total length of about $1400 \mathrm{~km}^{2}$. The beginning of the modern drainage system dates back to the end of the 19th century. It was then that the main collectors, located along the main watercourses (the Vistula, Rudawa, Wilga, and Białucha rivers), were built, receiving sewage from the area of Krakow. After the war Nowa Huta was built nearby, which, as a separate district of the town, has its own separate drainage system. This system is mainly of combined character. The separated system for sanitary sewage and rainwater started to be built 30 years ago. The Krakow system is separated by the Vistula River into two subsystems: The Vistula Left Bank System with its collector on the left of the river and The Vistula Right Bank System with its own collector on the right bank. Because of the fact that in stormy weather the collectors receive a huge amount of water, they have been equipped with overflows, or, in case of the rain drains, outlets into the receivers. On the Vistula right and left bank collectors there are 15 storm overflows, 8 of the Wilga, 5 of the Rudawa, 12 of the Białucha, and 5 of the Dłubnia. In the Krakow area there functions a drainage system whose elements are natural watercourses (streams, rivers), with the total length of about $95 \mathrm{~km}$; draining trenches, whose total length - together with the ditches on private lands-is about $628 \mathrm{~km}$, roadside gutters $55.6 \mathrm{~km}$ in length, and rainwater culvert system, $266.5 \mathrm{~km}$, with rain inlets.

A very important factor connected with a proper functioning of the sewer system, from the hydraulics point of view as well as polluting the receivers, is the volume of sludge, both organic and inorganic and the load of pollutants combined with solid particles (Table 5).

3.6. The Geoenvironmental Conditions of the Wilga and Pradnik Drainage Basins. The Wilga drainage area (W), the right-hand bank tributary of the Vistula, has its beginning in Pogórze Wielickie, in the district of Wieliczka, in the Pawlikowice village, 370 meters above the sea level. It is covered by loess and quaternary soils and, in the area of Swoszowice, there are silts showing up with admixture of fine fractions, with some sands as well as limestone outcrops 
TABLE 5: The sediment load extracted during hydraulic cleaning of the Krakow's sewerage (source: Municipal Department of Water Pipes and Sewers in Krakow).

\begin{tabular}{ll}
\hline The extracted sediment $\left[\mathrm{m}^{3}\right]$ & Years \\
\hline 16890 & 2005 \\
16138 & 2004 \\
14768 & 2003 \\
14067 & 2002 \\
\hline
\end{tabular}

and sulphur-bearing marls. In the area of Wróblowice there are outcrops of siltstones and sandstones. The river's length, within the town limits, is about $10 \mathrm{~km}$, which is $50 \%$ of its length and its water flow ranges between 0.12 and $1.07 \mathrm{~m}^{3} / \mathrm{s}$. The Wilga drains the area of $101 \mathrm{~km}^{2}$ and with the river net density of $1 \mathrm{~km} / 1 \mathrm{~km}^{2}$ catchment area. Within the urban infrastructure the outlet part of the river, $6.3 \mathrm{~km}$ long, has been regulated and its last section, $1.2 \mathrm{~km}$ long, has been dug and straightened as well as embanked, because of the backflow from the Dąbie regulating dam. Along the course of the Wilga River there are 8 storm spillways, which discharge rainwater and industrial sewage to it. The substrate of the bottom is mixed gravel and sand material, and, what should be pointed out is that the presence of the "White Seas" significantly changed its composition. The soda manufacture in Borek Fałęcki was opened in 1906. $\mathrm{Na}_{2} \mathrm{CO}_{3}$ was mainly produced then (about 5 tons a day) and so was some of $\mathrm{NaOH}$. The waste materials deposited in the Wilga drainage area are strongly alkaline ( $\mathrm{pH}$ 11-12) and saline. At the boundary of natural ground and the settling ponds there appeared a layer of rock hard ground, about one meter thick, with properties resembling that of lean concrete. This results from chemical reactions between strongly alkaline leachates, rich in calcium and the natural ground $[33,34]$.

The springs of the Prądnik (Bialucha) (P) flow from the Sułoszowa village, $431 \mathrm{~m}$ above the sea level, from where, with an even incline of about $2,7 \%$ o the river flows in a deeply cut valley between two main communication routes. The drainage area is mainly covered with quaternary formations, represented by Holocene clays, silt, sands, and gravels of the floodplains level and above. At places there are Pleistocene sands and periglacial gravels and loesses. The drainage area of the river is $192 \mathrm{~km}^{2}$, and the length of its urban section is $8.7 \mathrm{~km}$ long, $5.4 \mathrm{~km}$ of which were regulated. In its mouth section in 1949 the bottom of its bed was lowered by about 3 meters, which in the successive years was greatly reduced by an intensified accumulation of sediments. Regulation of its bed involved strengthening of its banks, at places with natural stone and somewhere else with man-made material. In 1997 a significant amount of regulating work was carried out in connection with building road junction of Aleja 29 Listopada-Opolska-Lublańska.

3.7. Classification of Sediments and River Suspension Quality. To assess the quality of the sediments in line with geochemical criteria [12, 16, 35], a three-step classification is used. According to legal, both Polish and American, environmental regulations, it can be verified if the sediments taken from the bottom of drains and water basins are polluted or can pose a problem from ecotoxicological point of view (Table 6). Based on the analysis of the heavy metals content determined in the samples of sediments gathering in various objects of municipal sewage infrastructure in southern Poland, and particularly in the area of Krakow, an independent, threestage classification (Table 7) has been developed for the waste water sediments. Based on the classification above it can be concluded that, from a geochemical standpoint, water sediments of the Vistula within the Krakow limits as well as in the catchment area of the Prądnik and Wilga belong to the group of poor and polluted ones. As far as the quality of suspended sediments is concerned, because of the heavy metals content according to LAWA classification (Table 8) [20], they belong to strongly ( $\mathrm{Cr}, \mathrm{Cu}, \mathrm{Ni}, \mathrm{Pb}$, and $\mathrm{Zn}$ ) and very strongly $(\mathrm{Cd})$ contaminated class.

\section{Conclusions}

The watercourses in Krakow and especially the Vistula River are polluted to a significant extent, which is indicated by cumulations of cadmium and lead in the water sediments, in the suspension and in water. The sediments coming from the drainage system infrastructure show quite well the level of anthropopressure in the drainage area. Usually the monitoring tests verifying the compliance with the water regulations are limited to the concentration of general suspension, COD, WWA and $\mathrm{Pb}$ in surface runoffs. Representative sampling of the sediments from the rain drains enables qualifying the drainage areas from the perspective of environmental risks. It seems important to measure, in case of exceeding the norms in rain wastewater, the metals should be measured in sediments and in suspension from the rain collectors and the area of their inlets into the receiver. Introducing fees for the presence of metallic pollutants in drainage system sediments should result in increased care for water environment. The water environment of the Vistula River is polluted with heavy metals which major source is its import from Silesian Industraial Area, but also, as the research shows, the surface runoff brings additional charge of metals. Water and sewage management in Krakow still generates pollution, and the environment protection instruments, used so far, are not sufficient-the condition of the Vistula River sediments and suspension contamination with $\mathrm{Cd}$ and $\mathrm{Pb}$ since the 1980s has not been significantly improved.

With reference to FDEF environmental standards, taking $\mathrm{Cd}$ and $\mathrm{Pc}$ contents into account, they belong to poor and contaminated sediments, and they are waste material, according to Polish regulations, especially when the sediments undergo dredging. Against own research of sewerage sediments they correspond to "polluted" and "unacceptable" because of potential reemission of pollutants. And the Vistula suspension belongs to class III, or even IV for Cd, and III-IV and IV for PB.

Hydrotechnical objects connected with draining rainwater constitute, together with sediments from storm sewers in Krakow, the driving forces (D), with a significant pressure factor $(\mathrm{P})$, which influence the hydromorphological condition of the watercourses and physio-chemical condition (S) of their 
TABLE 6: Classification of bottom water sediments presented on the basis of geochemistry standards [16].

\begin{tabular}{|c|c|c|c|c|c|c|}
\hline \multirow[b]{2}{*}{ Metal } & \multirow{2}{*}{ Geochemical background } & \multicolumn{3}{|c|}{ Sediments class/group } & \multirow{2}{*}{$\begin{array}{l}\text { Material excavated } \\
\text { Contaminated }^{*}\end{array}$} & \multirow{2}{*}{$\begin{array}{l}\text { Water sediments } \\
\mathrm{TEL}^{* *} / \mathrm{PEL}^{* * *}\end{array}$} \\
\hline & & I weak & II poor & $\begin{array}{l}\text { III contaminated } \\
\mathrm{mg} / \mathrm{kg}\end{array}$ & & \\
\hline $\mathrm{Cd}$ & $<0.5$ & 1 & 5 & 20 & 7.5 & $0.676 / 4.21$ \\
\hline $\mathrm{Cr}$ & 6 & 20 & 100 & 500 & 200 & $52.3 / 160$ \\
\hline $\mathrm{Ni}$ & 5 & 30 & 50 & 100 & 75 & $15.9 / 42.8$ \\
\hline $\mathrm{Cu}$ & 6 & 20 & 100 & 200 & 150 & $18.7 / 108$ \\
\hline $\mathrm{Pb}$ & 15 & 50 & 200 & 500 & 200 & $30.2 / 112$ \\
\hline $\mathrm{Zn}$ & 73 & 200 & 500 & 1000 & 1000 & $124 / 271$ \\
\hline
\end{tabular}

Polish environmental standards and sediment quality assessment guidelines (SQAGs) of Florida Department of Environmental Protection (FDEP).

*The kinds and concentrations of substances which cause the excavated material to be contaminated [23].

${ }^{* *}$ Toxic Effect Level, ${ }^{* * *}$ Probable Effect Level [24].

TABLE 7: Ranges of element concentrations $(\mathrm{mg} / \mathrm{kg})$ for relevant pollution classes of water drainage sediments [20].

\begin{tabular}{|c|c|c|c|c|}
\hline \multirow{5}{*}{ Metal } & \multicolumn{4}{|c|}{ Pollution classes of sediments } \\
\hline & \multicolumn{3}{|c|}{ Water drainage sediments } & \multirow{4}{*}{$\begin{array}{c}\text { Sludge sewage } \\
\text { In force } \\
\text { Acceptable }\end{array}$} \\
\hline & 1 & 2 & 3 & \\
\hline & \multicolumn{3}{|c|}{ Suggested } & \\
\hline & <acceptable & Polluted & > unacceptable & \\
\hline \multicolumn{5}{|l|}{$\overline{\mathrm{Cd}}$} \\
\hline g & $<0.5$ & $0.5-9$ & $>9$ & \multirow{2}{*}{$10-50$} \\
\hline d & $<1$ & $1-12$ & $>12$ & \\
\hline \multicolumn{5}{|l|}{$\mathrm{Ni}$} \\
\hline g & $<7$ & $7-26$ & $>26$ & \multirow{2}{*}{$100-500$} \\
\hline $\mathrm{d}$ & $<17$ & $17-42$ & $>42$ & \\
\hline \multicolumn{5}{|l|}{$\mathrm{Cr}$} \\
\hline g & $<6$ & $6-56$ & $>56$ & \multirow{2}{*}{$500-2500$} \\
\hline $\mathrm{d}$ & $<11$ & $11-61$ & $>61$ & \\
\hline \multicolumn{5}{|l|}{$\mathrm{Cu}$} \\
\hline g & $<51$ & $51-129$ & $>129$ & \multirow{2}{*}{$800-2000$} \\
\hline $\mathrm{d}$ & $<87$ & $87-200$ & $>200$ & \\
\hline \multicolumn{5}{|l|}{$\mathrm{Pb}$} \\
\hline g & $<50$ & $50-153$ & $>153$ & \multirow{2}{*}{$500-1500$} \\
\hline d & $<120$ & $120-234$ & $>234$ & \\
\hline \multicolumn{5}{|l|}{$\mathrm{Zn}$} \\
\hline g & $<229$ & $229-729$ & $>729$ & \multirow{2}{*}{$2500-5000$} \\
\hline d & $<434$ & $434-1100$ & $>1100$ & \\
\hline
\end{tabular}

g: if $<0.18 \mathrm{~mm} \mathrm{Fr}$. is $<25 \%$ of weight, $\mathrm{d}$ : if $<0.18 \mathrm{~mm} \mathrm{Fr}$. is $\geq 75 \%$ of weight.

water environment. The structure of heavy metal binding in rainwater drain sediments, through the coagulation and aggregation processes, do not show significant differences between the content of finer and coarser fractions. Also, the sediments show significant lack of homogeneity, due to which the results for the doubled samples show differences up to $30 \%$. Next, the bottom sediments of the Vistula River in the vicinity of the spillovers are varied as far as the degree of metal binding with the sediment particles is concerned, and generally this is in line with the sorption ability of the mineral components they consist of. Most often, the finest fraction contains the biggest share of pollution. There are situations of greater concentrations in the medium and coarser fractions. The explanation of this phenomenon will be the subject of a separate study, because it demands scanning microscopy.

The diversification of the pollution of the Vistula bottom sediments in the bank section shows significant but nonuniform level of metal concentrations. A small distance from the shore or the places at the bridge pillars where sediments were obtained, encourages the conclusion that this indicator should be used with discretion for 21 monitoring purposes. Riverbed processes, river transport, storm spillovers, tributaries mouths, or flood waters are the main factors changing sediment structure and their pollution level. Petitioning for short- or long-term changes, without special ways of collecting sediments or sampling them can generate a succession of mistakes. So far, researches of others, as well as the author's own work, show that monitoring the pollution of suspended sediments caught into specially constructed and placed traps suited this kind of solid particles, and specific schedule of collecting these samples is probably the only effective solution. Taking the sediment cross sections or only their surface layer is not able to guarantee a representative character of samples. Rainwater drainage sediments or storm spillovers also show variability but collector or spillover construction limits, to some extent, their diluting or random pollution. They also serve as traps of sort and following the course of the sewer system enables determining the causing factor more effectively and its elimination.

The articles from the Polish Journal of Laws 2007.75.493 in the Act on "preventing the environmental damage and repairing it" is an attempt to implement the "polluter pays principle," in line with the 2004/35/WE directive of the European Parliament and Council from the 21 April, 2004, concerning responsibility for preventing and damage reparation in the environment-Official journal of the $\mathrm{EU} \mathrm{Nb}$ 143 p. 56. The European Water Charter was proclaimed in Strasbourg already in 1968, but most people are not aware of its existence and the meaning of its content.

In the past and at present when the time is peaceful and we are free from natural disasters, we live "with our backs turned towards water," not respecting the environment; this weakens the condition of both town and society. Maybe the initiative started in August 2013 in Krakow to stop the rainwater within the municipal drainage area is the last attempt to "bring us 
TABLE 8: Limiting contents [mg/kg] of heavy metals in suspended matter of river water for LAWA classes [10].

\begin{tabular}{|c|c|c|c|c|c|c|c|}
\hline LAWA class & I & \multicolumn{5}{|c|}{ Upper limit [mg/kg] } & IV \\
\hline $\mathrm{Cd}$ & $<0.3$ & $<0.6$ & $<1.2$ & $<2.4$ & $<4.8$ & $<9.6$ & $>9.6$ \\
\hline $\mathrm{Cr}$ & $<80$ & $<90$ & $<100$ & $<200$ & $<400$ & $<800$ & $>800$ \\
\hline $\mathrm{Cu}$ & $<20$ & $<40$ & $<80$ & $<160$ & $<320$ & $<640$ & $>640$ \\
\hline $\mathrm{Ni}$ & $<30$ & $<40$ & $<50$ & $<100$ & $<200$ & $<400$ & $>400$ \\
\hline $\mathrm{Pb}$ & $<25$ & $<50$ & $<100$ & $<200$ & $<400$ & $<800$ & $>800$ \\
\hline $\mathrm{Zn}$ & $<100$ & $<200$ & $<400$ & $<800$ & $<1600$ & $<3200$ & $>3200$ \\
\hline \multicolumn{8}{|c|}{ Degree of solid particles pollution } \\
\hline & Not polluted & $\begin{array}{c}\text { Not polluted to } \\
\text { moderately polluted }\end{array}$ & $\begin{array}{l}\text { Moderately } \\
\text { polluted }\end{array}$ & $\begin{array}{l}\text { Moderately polluted } \\
\text { to strongly polluted }\end{array}$ & $\begin{array}{l}\text { Strongly } \\
\text { polluted }\end{array}$ & $\begin{array}{l}\text { Strongly polluted to } \\
\text { very strongly polluted }\end{array}$ & $\begin{array}{c}\text { Very strongly } \\
\text { polluted }\end{array}$ \\
\hline
\end{tabular}

back to earth" (and to water!) and notice the abuse of water by earlier and present generations. "In the summer (14 July, 1834) the inhabitants of Krakow used the Vistula River for recreation. The riverbed was not deep, here and there the water was cleft by sandbanks, and the riversides were covered by light, fine sand. Some years were particularly hot, so the cool waters of the river were then solace..." [36]. Was this possible in 2013, during the hot summer? Unfortunately, not!

\section{Conflict of Interests}

The author declares that there is no conflict of interests regarding the publication of this paper.

\section{Acknowledgments}

The author would like to express her special gratitude to Tomek Czapliński from Municipal Department of Water and Sewage Management, for all his help in the collectors abyss; and to Robert Szota from Department of Municipal Infrastructure and Transport, for facilitating sediment sampling in the rain drainage, ditches, and drainage beds. The author thanks her diploma students-Milena Futet, Monika Zając, Artur Mazur, Przemek Kowal, and Konrad Kowal, and her son, Maksymilian Pawlikowski, who accompanied them and recorded their field work. Ania Hardek was very helpful showing exceptional understanding with translating this publication, for which the author wanted to express to her her gratefulness.

\section{References}

[1] J. Diwakar and J. K. Thakur, "Environmental system analysis for river pollution control," Water, Air, \& Soil Pollution, vol. 223, no. 6, pp. 3207-3218, 2012.

[2] B. Buszewski, J. Kowalska, J. Pacyna, A. Kot, and J. Namieśnik, "Interactions between river catchments and the coastal zone: the EuroCat-VisCat project," Oceanological Studies, vol. 31, no. 1-2, pp. 107-116, 2002.

[3] E. Fagbote Olubunmi and E. O. Olanipekun, "Evaluation of the status of heavy metal pollution of water (surface and ground) and aquatic macrophyte (Ceratophyllum demersum) of Agbabu
Bitumen Deposit Area, Nigeria," British Journal of Applied Science \& Technology, vol. 3, no. 2, pp. 289-306, 2013.

[4] T. Stoyanova, I. Traykov, I. Yaneva, and V. Bogoev, "Accumulation of heavy metals in the macrozoobenthos of the Luda River, Bulgaria," Biotechnology and Biotechnological Equipment, vol. 26, no. 3, pp. 2981-2986, 2012.

[5] M. Pawlikowski, E. Szalińska, M. Wardas, and J. Dominik, "Chromium originating from tanneries in river sediments: a preliminary investigation from the upper Dunajec River (Poland)," Polish Journal of Environmental Studies, vol. 15, no. 6, pp. 885-894, 2006.

[6] J. B. Ellis and D. M. Revitt, "Incidence of heavy metals in street surface sediments: solubility and grain size studies," Water, Air, and Soil Pollution, vol. 17, no. 1, pp. 87-100, 1982.

[7] I. Bojakowska, "Wpływ odprowadzania ścieków na akumulację metali ciężkich w osadach wybranych rzek Polski, Instrukcje i metody badań geologicznych," Polish Geological Review, vol. 55, p. 78, 1995.

[8] J. Brils, "Sediment monitoring under the EU Water Framework Directive," Journal of Soils and Sediments, vol. 4, no. 2, pp. 72-73, 2004.

[9] E. Adamiec and E. Helios-Rybicka, "Distribution of pollutants in the odra river system part iv. Heavy metal distribution in water of the upper and middle Odra River, 1998-2000," Polish Journal of Environmental Studies, vol. 11, no. 6, pp. 669-673, 2002.

[10] E. Adamiec, U. Aleksander, L. Budek et al., "Chemical speciation, accumulation and mobilization of heavy metals in suspended matter and bottom sediments of the Odra River and their tributaries,' Final Report Sub-Project 3, International Oder Project, 2002.

[11] W. Salomons, "Sediments in the catchment-coast continuum," Journal of Soils and Sediments, vol. 5, no. 1, pp. 2-8, 2005.

[12] G. Müller, "Schwermetalle in den Sedimenten des Rheins," Veranderung seit, vol. 79, pp. 778-783, 1971.

[13] U. Förstner and G. T. W. Wittmant, Metal Pollution in the Aquatic Environment, Springer, Berlin, Germany, 1979.

[14] P. Woitke, J. Wellmitz, D. Helm, P. Kube, P. Lepom, and P. Litheraty, "Analysis and assessment of heavy metal pollution in suspended solids and sediments of the river Danube," Chemosphere, vol. 51, no. 8, pp. 633-642, 2003.

[15] B. Koukal, J. Dominik, D. Vignati et al., "Assessment of water quality and toxicity of polluted Rivers Fez and Sebou in the region of Fez (Morocco)," Environmental Pollution, vol. 131, no. 1, pp. 163-172, 2004. 
[16] I. Bojakowska and G. Sokołowska, "Geochemiczne klasy czystości osadów wodnych," Przeglad Geologiczny, vol. 46, no. 1, pp. 49-54, 1998.

[17] W. Calmano, W. Ahlf, and U. Förstner, "Sediment quality assessment: chemical and biological approaches," in Sediments and Toxic Substances: Environmental Effects and Ecotoxicity, W. Calmano and U. Förstner, Eds., pp. 1-35, Springer, Berlin, Germany, 1996.

[18] S. L. Smith, D. D. MacDonald, K. A. Keenleyside, C. G. Ingersoll, and L. J. Field, "A preliminary evaluation of sediment quality assessment values for freshwater ecosystems," Journal of Great Lakes Research, vol. 22, no. 3, pp. 624-638, 1996.

[19] M. Wardas, U. Aleksander-Kwaterczak, S. Jusik et al., "An attempt to assess the impact of anthropopressure on the ecological state of urbanised watercourses of krakow conurbation and the difficulties encountered," Journal of Elementology, vol. 15, no. 4, pp. 725-743, 2010.

[20] M. Wardas, "Próba oceny i klasyfikacji osadów systemów wodno-ściekowych pod względem zanieczyszczenia metalami ciężkimi," Ekologia i Technika, suplement 14, pp. 5-98, 2006.

[21] M. Wardas, L. Budek, and E. Helios Rybicka, "Variability of heavy metals content in bottom sediments of the Wilga River, a tributary of the Vistula River (Krakow area, Poland)," Applied Geochemistry, vol. 11, no. 1-2, pp. 197-202, 1996.

[22] E. Helios-Rybicka, "Accumulation and mobilisation of heavy metals in the aquatic sediments, dated sediments as chronological factor," in Proceedings of the Conference Geological Aspects of Environmental Protection, pp. 17-24, AGH, Kraków, Poland, 1991.

[23] "The kinds and concentrations of substances which cause the excavated material to be contaminated (Rodzaje oraz stężenia substancji, które powodują, że urobek jest zanieczyszczony)," Polish Journal of Laws, vol. 55, p. 498, 2002.

[24] "Florida Sediment Quality Assessment Guidelines," http://www .dep.state.fl.us/waste/quick_topics/publications/.

[25] J. Motyka and A. Postawa, "The groundwater of Zakrzówek Horst (S Kraków-Częstochowa upland)," Biuletyn-Panstwowego Instytutu Geologicznego, no. 412, pp. 71-130, 2004.

[26] M. Wardas, U. Aleksander-Kwaterczak, E. Łojan, P. Woźniak, and Ł. Wolski, "Inwentaryzacja źródeł i ocena poziomu zanieczyszczenia metalami ciężkimi osadów dennych rzeki Prądnik-Białucha w Krakowie, celem określenia potencjału ekologicznego," Infrastruktura i Ekologia Terenów Wiejskich, vol. 3-4, pp. 161-169, 2006.

[27] M. Wardas, M. Pawlikowski, A. Korzeniak, A. Basińska, R. Szota, and M. Kłek, "Heavy metals in sediments of water and wastewater system in Cracow," Environmental Protection Engineering, vol. 28, no. 1, pp. 35-41, 2002.

[28] M. Matysik and D. Absalon, "Renaturization plan for a river valley subject to high human impact-hydrological aspects," Polish Journal of Environmental Studies, vol. 21, no. 2, pp. 249257, 2012.

[29] B. Osmólska-Mróz, "Zasady kształtowania jakości wód w małych ciekach na terenach miejskich," in Zaopatrzenie w wodę. Wytyczne technologiczne wysokoefektywnych metod oczyszczania ścieków, J. Bernacka, M. Błażejewski, and K. Słysz, Eds., pp. 45-72, Instytut Ochrony Środowiska, Warsaw, Poland, 1990.

[30] H. Sawicka-Siarkiewicz, P. Blaszczyk, and P. Błaszczyk, Urzadzenia kanalizacyjne na terenach zurbanizowanych: Wymagania techniczne $i$ ekologiczne, Instytut Ochrony Środowiska, Warszawa, Poland, 2007.
[31] J. Pociask-Karteczka, "Przemiany stosunków wodnych na obszarze Krakowa, Zeszyty Naukowe UJ," Prace Geograficzne, vol. 96, pp. 7-53, 1994.

[32] J. Pociask-Karteczka, "Płynie Wisła, płynie," in Tu wszystko jest Polską...Eseje krajoznawcze o Krakowie i Małopolsce, J. Partyka, Ed., pp. 41-80, Oddział Krakowski PTTK im, Kraków, Poland, 2009.

[33] W. Sroczyński, "Geological condition of revitalization and land development the "Białe Morza" on the terrains after "Solway" Krakow Soda Works," Geologia, vol. 34, no. 4, pp. 701-709, 2008.

[34] R. Wójcik and Ł. Zawadzki, "Anion leachability from the top layer of the Cracow Soda waste dumps," Environmental Protection and Natural Resources, vol. 49, pp. 433-442, 2011.

[35] K. K. Turekian and K. H. Wedepohl, "Distribution of the elements in some major units of the earth's crust," Bulletin of the Geological Society of America, vol. 72, no. 2, pp. 175-192, 1961.

[36] K. Grodziska, Gdzie miasto zaczarowane. Księga cytatów o Krakowie, Znak, Kraków, Poland, 2003. 

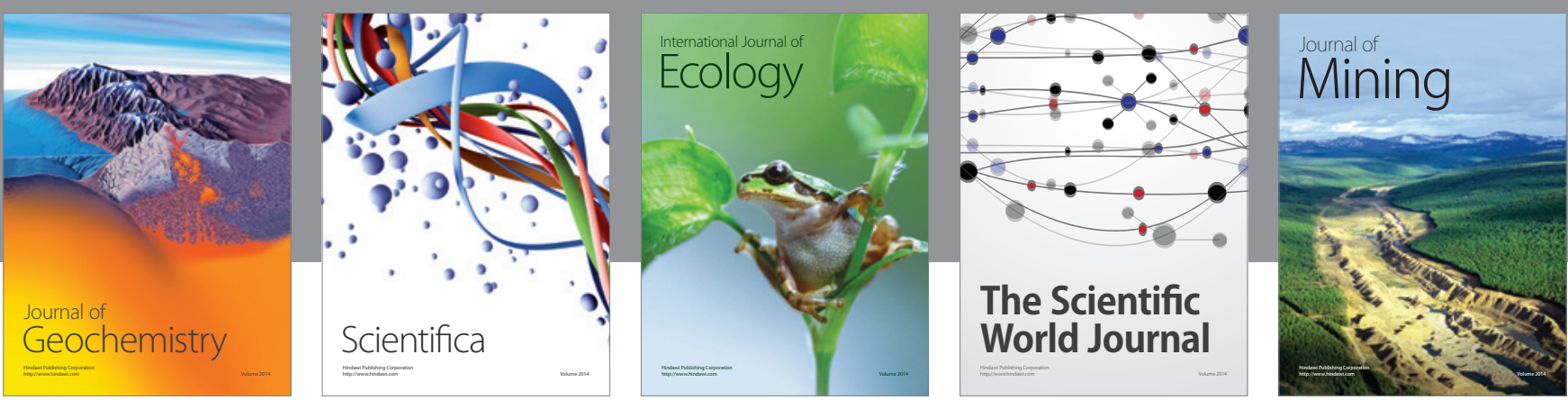

The Scientific World Journal
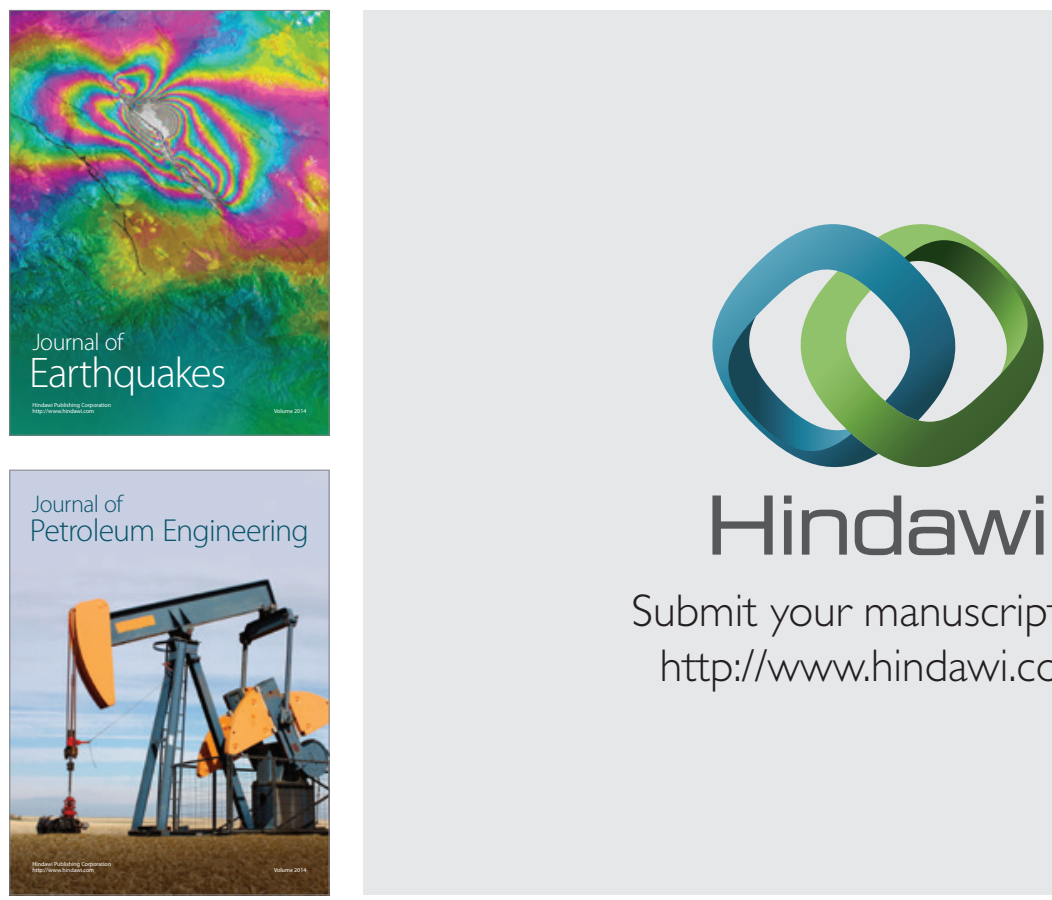

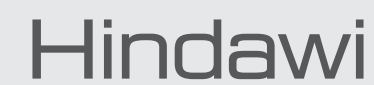

Submit your manuscripts at

http://www.hindawi.com
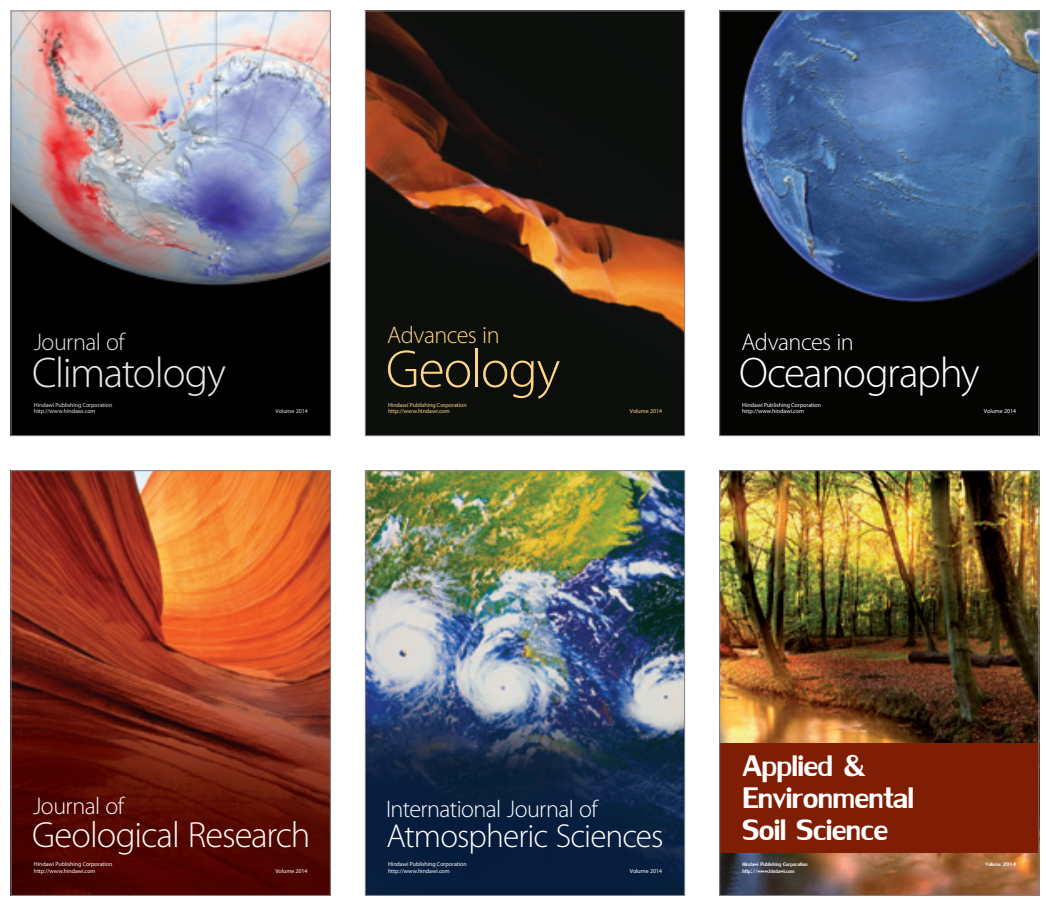
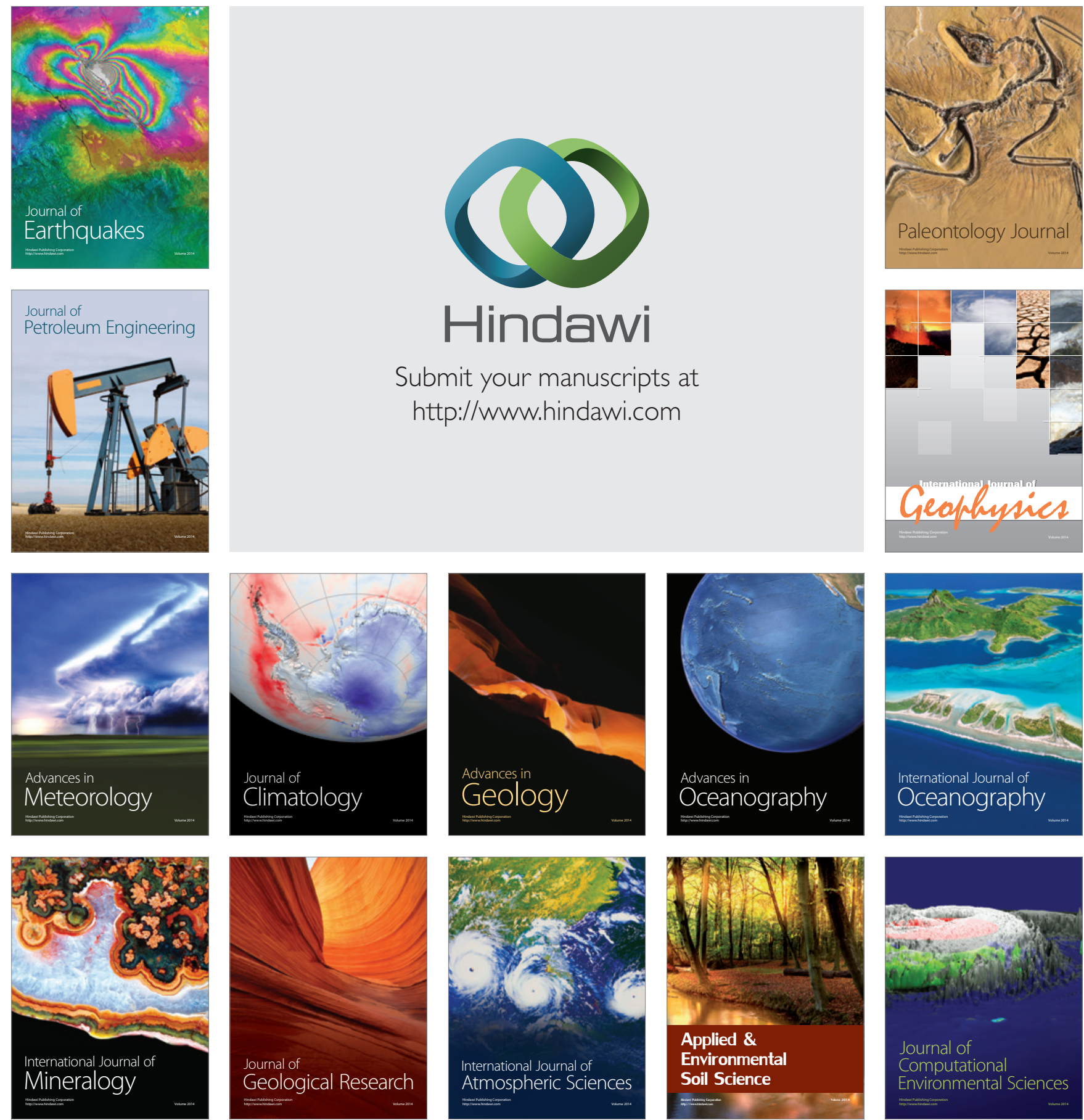